\title{
Effect of chloretracycline and albendazole on alkaline phosphatase activity of carp gill (Cyprinus carpio L.)
}

\author{
I. Kurbatova', M. Zakharenko', O. Yaremchuk², L. Chepil'1, V. Polyakovksiy ${ }^{1}$ \\ ${ }^{1}$ National University of Life and Environmental Science, \\ General Rodimcev St. 19, Kiev, 03041, Ukraine \\ ${ }^{2}$ Vinnytsia National Agrarian University, Sonyachna Str. 3, Vinnytsia, 21008, Ukraine \\ *Corresponding authorE-mail: innakurbatova@ukr.net \\ Received: 19.08.2020. Accepted 30.09.2020
}

\begin{abstract}
The effect of the antibiotic chlortetracycline and the anthelmintic albendazole on morphological features, internal organs, alkaline phosphatase activity and protein content in the gills of two-year-old carp was studied. It was found that chlortetracycline and albendazole at the studied concentrations in water and short-term action do not affect the morphological features, behavior and internal organs, but change the alkaline phosphatase activity of the gills of two-year-old carp. The antibiotic chlortetracycline at concentrations of $1.10,3.15$, and $6.30 \mathrm{mg} / \mathrm{dm} 3$ of water and fish exposure for $72 \mathrm{~h}$ reduced the alkaline phosphatase activity of gills in carp of the first experimental group by 2.5 times, in the second - by 2.8 times and in the third by 2.7 times regard the control; it did not affect the protein content in the gills, morphological features and internal organs of fish. We registered an increase in alkaline phosphatase activity of gills in two-year-old carp under effect of anthelmintic albendazole at at the concentration of $1.0 \mathrm{mg} / \mathrm{dm} 3$ by $28.2 \%$, while albendazole concentration of 0.2 and $0.5 \mathrm{mg} / \mathrm{dm} 3 \mathrm{did}$ not affect the alkaline phosphatase activity as well as the level of protein in fish body. Our results indicate an important role of gill alkaline phosphatase in assessing the negative effects of antibiotics and water anthelmintics in freshwater fish.
\end{abstract}

Key words: freshwater fish, morphological features, respiratory organs, antibiotic, anthelmintic, protein.

\section{Introduction}

Livestock enterprises and veterinary facilities have a significant impact on the functioning of aquatic ecosystems (Bártíková et al., 2015; Tertychna et al., 2017; Prichepa et al., 2019). This is especially true for regions with developed livestock, the technology of which provides a significant concentration of animals or poultry in limited areas, which involves the use of a large number of antibiotics and anthelmintics to maintain the health of livestock (Bártíková et al, 2010). Water bodies located in the area of activity of such enterprises are subject to constant anthropogenic pressure due to repeated discharge into wastewater bodies contaminated with residues of veterinary drugs for therapeutic and prophylactic purposes, most of which are toxic compounds for aquatic organisms (Khomych \& Mytiai, 2015; Degtyarenko et al., 2018; Tonelli et al., 2020).

The most common antibacterial drugs found in the area of livestock enterprises are tetracyclines, fluoroquinolones, nitrofurans and macrolides (Li, 2019; Chen, 2020). In addition to these xenobiotics, sulfonamides, anthelmintics, and hormonal compounds have also been found in livestock waste, wastewater, soils, and natural bodies of water (Woodward, 2008; Cvilink et al., 2009). Excreted from the body of animals almost unchanged, antibiotics and anthelmintics accumulate in wastewater, are not removed during treatment at treatment plants and fall into natural bodies of water (Carvalho, 2016; Mehed et al., 2019; Kovalakova et al., 2020). This creates risks of antibiotics entering the food chains of water bodies and drinking water, which provides for constant monitoring of their presence and content in the wastewater of livestock enterprises (Bengtsson-Palme et al., 2018; Rodriguez-Mozaz et al., 2020).

The action of these xenobiotics of water on fish is associated with the impact on the gills, morphological features, internal organs, immune system, hematopoiesis and metabolism in organs and tissues (Kurbatova et al., 2018; Li, 2019; Grenni et al., 2018). The gills and hepatopancreas of fish are most negatively affected by xenobiotics, as evidenced by changes in the structure and function of these organs (Bártíková et al., 2015).

The aim of the study was to investigate the effect of the antibiotic chlortetracycline and the anthelmintic albendazole on alkaline phosphatase activity and protein content in the gills, morphological features and internal organs of carp (Cyprinus carpio L.) biennials. 


\section{Materials and methods}

The experiments were conducted at the Department of Animal Biology of the National University of Life and Environmental Sciences of Ukraine. The experiments used carp (Cyprinus carpio L.), two years old, weighing 450-500 g, which were kept in aquariums with a volume of $40 \mathrm{dm}^{3}$ for two individuals each.

The first series of experiments investigated the effect of chlortetracycline on the morphological characteristics of the internal organs of fish and the alkaline phosphatase activity of the gills. The antibiotic was added to the water before planting the fish, reaching concentrations of 1.10 (first), 3.15 (second) and $6.30 \mathrm{mg} / \mathrm{dm}^{3}$ (third experimental group). Chlortetracycline was not added to the aquarium water of fish of the control group. In the experiment, 16 two-year-old carp were used, four in each group.

The second series of experiments examined the effect of the anthelmintic albendazole on morphological features, internal organs, protein content and alkaline phosphatase activity of carp gills. For this purpose, the anthelmintic albendazole was added to the water of the first aquarium before planting, creating a concentration of $0.2 \mathrm{mg} / \mathrm{dm}^{3}$, in the second $-0.5 \mathrm{mg} / \mathrm{dm}{ }^{3}$, and in the third - $1 \mathrm{mg} / \mathrm{dm}^{3}$. Albendazole was not added to the water in which the fish of the control group were kept.

When keeping fish of the control and experimental groups in both experiments, the water was aerated and the oxygen content was maintained in the range of $6.5-7.5 \mathrm{mg} / \mathrm{dm}^{3}$, the temperature was $18-20^{\circ} \mathrm{C}$, and the $\mathrm{pH}$ value was 7.8 . During the experiment, the behavior of the fish and the number of respiratory movements were monitored. After $72 \mathrm{~h}$ of exposure in the control and experimental groups, the external signs were examined, namely the condition of the scales, gills, fins, eyes, mouth and anus, and then the carp were killed, the gills removed, cooled and the petals from which aqueous homogenates were prepared. The resulting homogenate of fish gills was centrifuged at $40{ }^{\circ} \mathrm{C}$ for $10 \mathrm{~min}$ at $4000 \mathrm{rpm}$ and selected the supernatant used for research. In parallel, monitored the condition of the internal organs of fish, which were removed after carcass slaughter, using for this purpose well-known methods (Kamyshnikov, 2009; Levchenko et al., 2012).

The protein content in the supernatant of carp gills was determined using Folin's reagent (Loury et al., 1951), and alkaline phosphatase activity was controlled by the method described by Kamyshnikov V.S. (Kamyshnikov, 2009).

The research results were statistically processed using Student's t-test and MS Excel add-in (Kokunin, 1975). Statictical significance was accepted as $\mathrm{p} \leq 0.05$.

\section{Results and discussion}

Chlortetracycline added to the aquarium water in various concentrations affects the respiratory system of fish - gills, as evidenced by the results of studies of the activity of one of the key enzymes of this organ - alkaline phosphatase (Lallès, 2019). Despite the fact that the carp of the experimental groups showed no signs of redness, change in size and color of the gill petals under the action of chlortetracycline, but found its effect on a number of intracellular processes in this organ. It was shown that the alkaline phosphatase activity of carp gills under the action of chlortetracycline was reduced in fish of the first experimental group by 2,5 times compared with the control. Increasing the concentration of chlortetracycline in aquarium water to $3,15 \mathrm{mg} / \mathrm{dm}^{3}$ in which fish of the second experimental group were kept reduced this figure by 2,8 times, and in carp of the third experimental group, which were in water with a concentration of this xenobiotic $6,3 \mathrm{mg} / \mathrm{dm}^{3} 2,7$ times compared with the control (Fig. 1). It should be noted that a significant increase in the concentration of chlortetracycline in water by 3,0 and 6,3 times, respectively, for fish of the second and third experimental groups, compared with the first, did not cause a further decrease in alkaline phosphatase activity in fish gills.

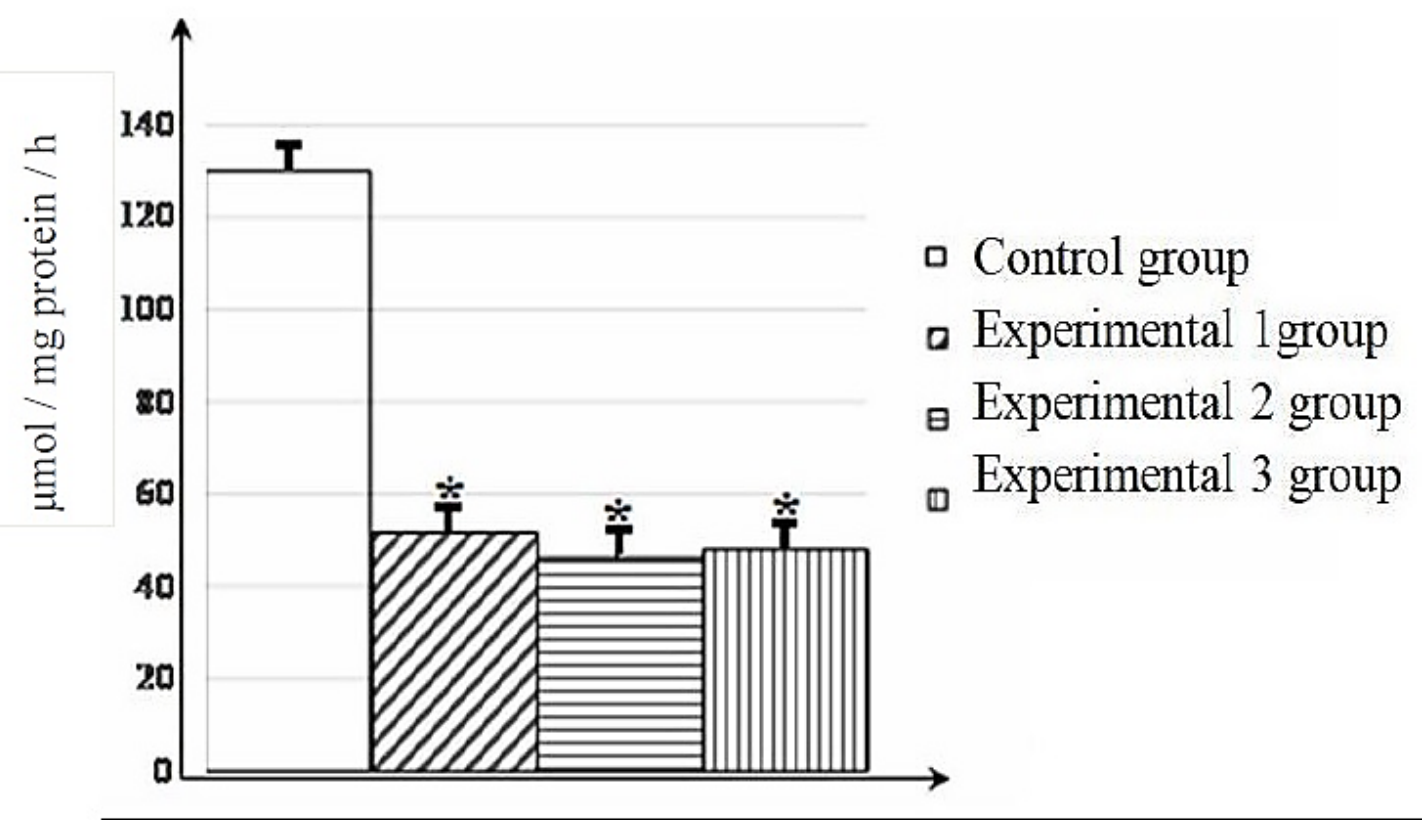

Fig. 1. Alkaline phosphatase activity of carp gills under the action of chlortetracycline, $n=4$. 
A significant decrease in alkaline phosphatase activity in the gills of carp under the action of chlortetracycline indicates a decrease in the hydrolysis of organophosphorus compounds, which in turn affects the functional state of this important organ for fish. Thus, control of alkaline phosphatase activity of fish gills can be one of the diagnostic tests of water contamination by antibiotics of the tetracycline group, even at low concentrations in water, which is consistent with the results of studies by other authors who studied the effect of xenobiotics on enzymes in fish gills (Lallès, 2019).

A significant increase in the concentration of chlortetracycline in water, despite a decrease in alkaline phosphatase activity in the gills of carp did not affect the protein concentration in this important organ for fish, which is primarily negatively affected by water toxicants (Fig. 2). It was found that the total protein content in the gills of fish of the first experimental group did not differ from the control, as in the carp of the second and third experimental groups. There was also no difference in protein content in the gills of biennials of carp of the first, second and third experimental groups, despite a significant increase in the antibiotic chlortetracycline in the aquarium water. The obtained data indicate no effect of this xenobiotic on the composition and structure of gill petals, which is probably due to the low concentration and short-term effect of chlortetracycline on fish, even with a significant increase in its level in the water.

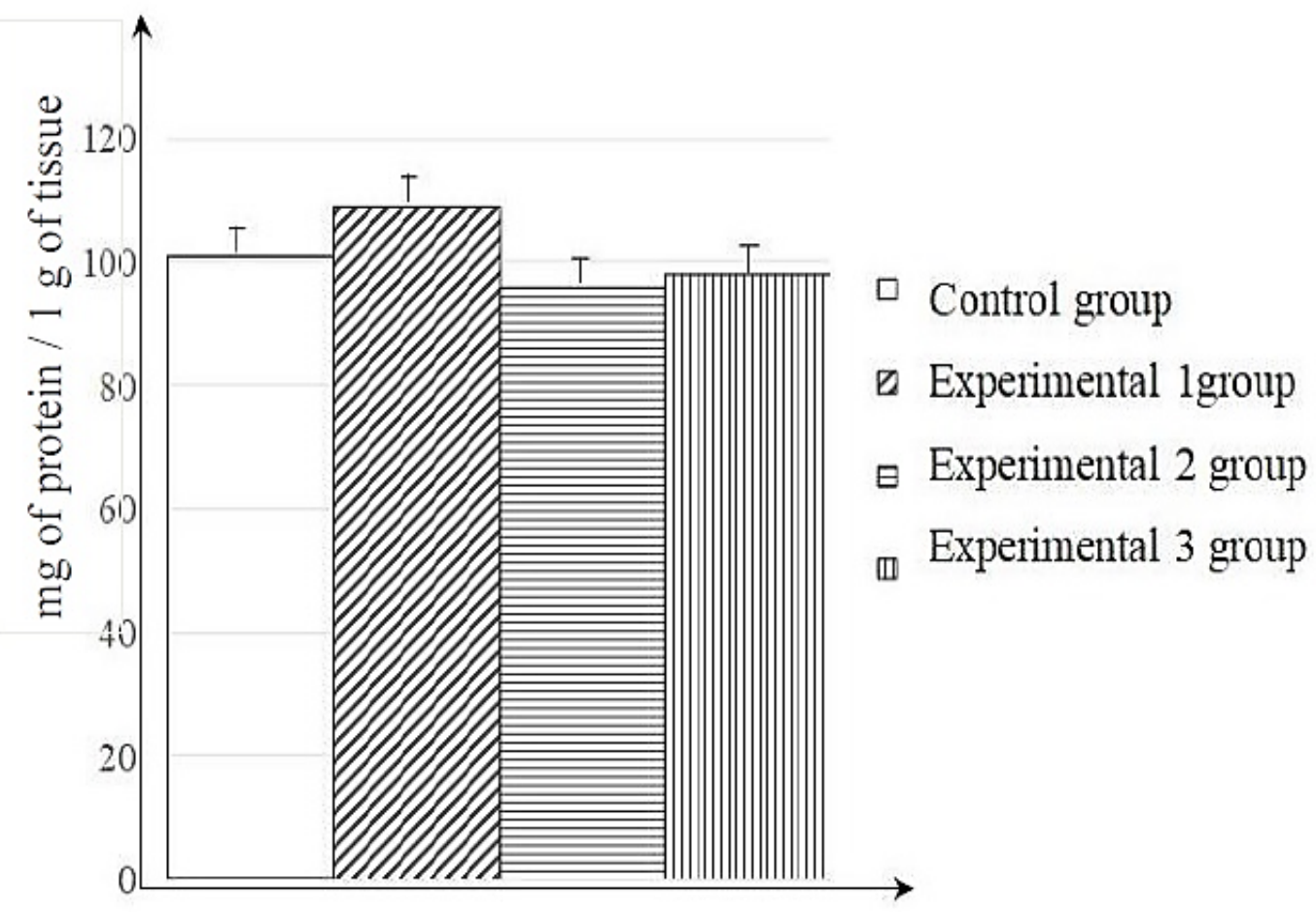

Fig. 2. The content of total protein in the gills of fish under the action of chlortetracycline, $n=4$.

This conclusion is confirmed by further studies on the effect of this xenobiotic on the body coverings and the condition of the internal organs of carp in the experimental groups compared to the control. In fish of the first, second and third experimental groups, which were kept in water with different concentrations of chlortetracycline, body position, number of respiratory movements, color of scales, fins, eye, mouth and anus did not change compared to control. Under the action of chlortetracycline water in carp of the experimental groups also showed no visible changes in color, consistency and size of the hepatopancreas, kidneys and intestines, which indicates the absence of its effect on the morphological parameters of internal organs. Therefore, at a concentration of $1.10,3.15$, and $6.30 \mathrm{mg} / \mathrm{dm}^{3}$ of water and short-term exposure chlortetracycline does not affect the morphological characteristics of fish, but changes the alkaline phosphatase activity of the gills, which may be an important test for bioindication of water contaminated with tetracycline antibiotics.

Widespread use of albendazole in livestock as an antiparasitic agent, as well as to combat helminthiasis of fish contributes to its spread in the environment (Cvilink et al., 2009). For aquatic organisms, as well as for warm-blooded animals, it is a toxic compound and significantly affects the internal organs, morphological parameters of the blood, the fractional protein composition of blood plasma of fish. It is found in the effluents of livestock enterprises and it enters the natural reservoirs with the wastewater of treatment plants, even after their biological treatment (Bártíková et al., 2010; Kurbatova et al., 2020).

Unlike the antibiotic chlortetracycline, the anthelmintic albendazole has more pronounced toxic properties and enters the water bodies in greater quantities (Kurbatova et al., 2018; Rodriguez-Mozaz et al., 2020). However, the presence of carp in water with concentrations of albendazole 0.2 (first), 0.5 (second) and $1.0 \mathrm{mg} / \mathrm{dm}^{3}$ (third experimental group) for 72 hours did not affect their behavior, the number of respiratory movements, morphological features and condition of internal organs. In fish of the experimental groups, the body covers, as well as fins, gill covers, head, eyes, mouth and anus, as well as the size, color, consistency of internal organs, namely the hepatopancreas, intestinal mucosa, kidneys and gill petals did not differ from control. The anthelmintic albendazole, added to the aquarium water only at a concentration of $1.0 \mathrm{mg} / \mathrm{dm}^{3}$, changed the alkaline phosphatase activity of carp gills, increasing its value in carp of the third experimental group by $28.2 \%$ compared with the control (Fig. 3). 


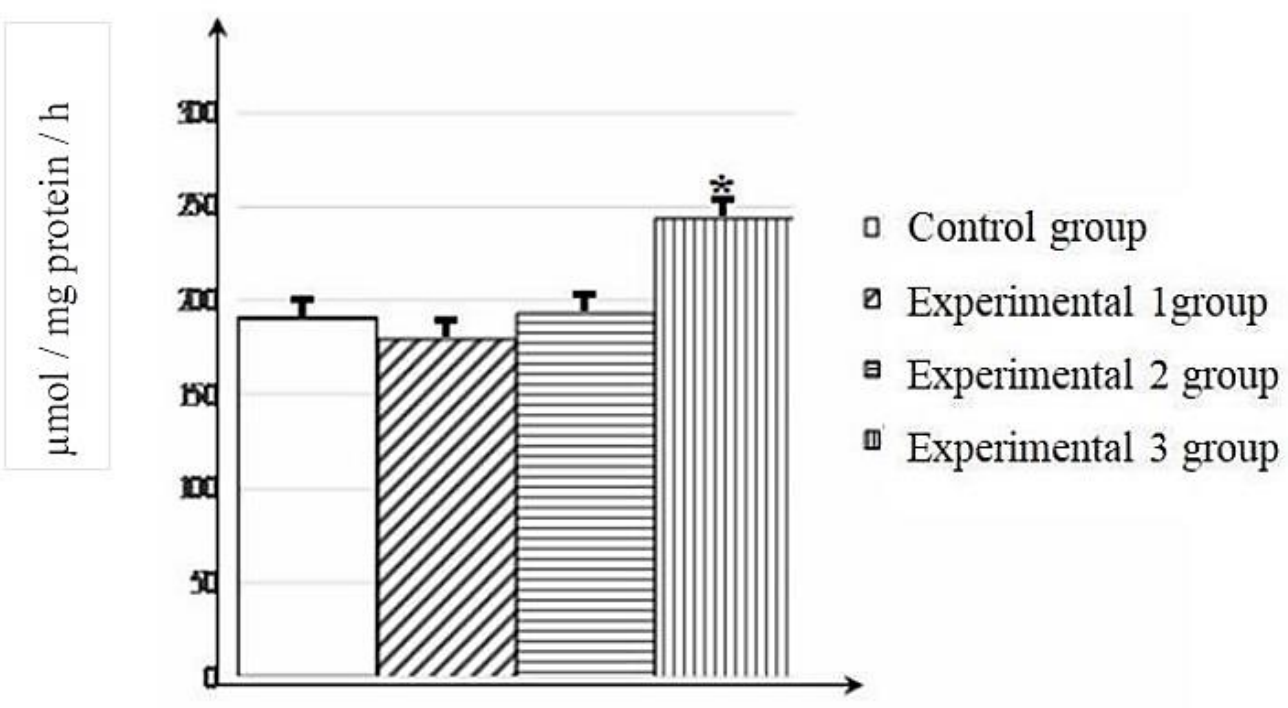

Fig.3. Alkaline phosphatase activity in carp gills under the action of albendazole, $n=4$

At lower concentrations in water, this xenobiotic did not affect the alkaline phosphatase activity of the gills of two-year-old carp. The absence of changes in the indicators of alkaline phosphatism activity of gills in fish of the first and second experimental groups, compared with the control, is probably due to the low concentration of albendazole in water and its short-term effect on two-year-old carp. There were also no differences between the protein content in the gills of fish of the first, second and third experimental groups and control (Fig. 4). The obtained data probably indicate the absence of structural changes in the gills of fish at low concentrations and short-term effects of this anthelmintic on fish.

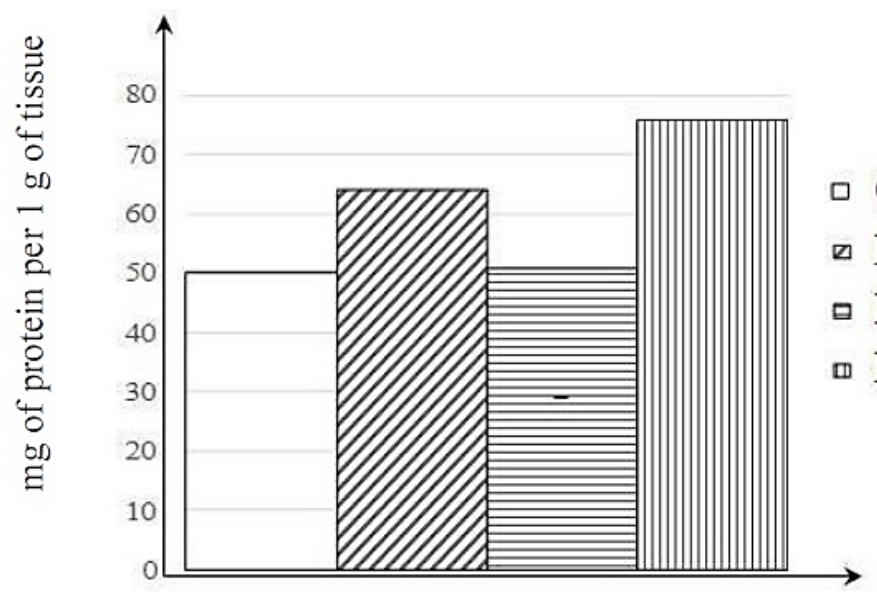

Fig. 4. Protein content in carp gills under the action of albendazole, $n=4$.

Therefore, albendazole at a concentration of $0.2,0.5$ and $1.0 \mathrm{mg} / \mathrm{dm}^{3}$ does not affect the morphological characteristics, internal organs, protein content in the gills of biennial carp. However, at a concentration of $1.0 \mathrm{mg} / \mathrm{dm}^{3}$ of water, it reduces the alkaline phosphatase activity in the gills of two-year-old carp, changing the intensity of the hydrolysis of organophosphorus compounds.

\section{Conclusion}

We found that the antibiotic chlortetracycline at a concentration of $1.10,3.15$ and $6.30 \mathrm{mg} / \mathrm{dm}^{3}$ of water with short-term action does not affect the morphological features and internal organs, the protein content in the gills of biennial carp, but significantly reduces the alkaline phosphatase activity in this organ. The effect of the anthelmintic albendazole on biennial carp depends on its concentration in water and is associated with a decrease in alkaline phosphatase activity of gills at a concentration of $1.0 \mathrm{mg} / \mathrm{dm}^{3}$ at constant values of morphological features, the state of internal organs of fish, protein content and alkaline phosphatase activity in gills in water 0.2 and $0.5 \mathrm{mg} / \mathrm{dm}^{3}$.

We suggest that evaluation of the chlortetracycline and albendazole effect on fish resistance could be the perspective research, which clarify fish adaptation to xenobiotics.

\section{References}


Bártíková H., Skálová L., Stuchlíková L., Vokřál I., Tomáš Vaněk, Radka Podlipná. (2015). Xenobiotic-metabolizing enzymes in plants and their role in uptake and biotransformation of veterinary drugs in the environment. Drug Metabolism Reviews, 47(3), $374-87$. doi:10.3109/03602532.2015.1076437

Bártíková H., Vokřál I., Skálová L., Lamka J., Szotáková B. (2010). In vitro oxidative metabolism of xenobiotics in the lancet fluke (Dicrocoelium dendriticum) and the effects of albendazole and albendazole sulphoxide ex vivo. Xenobiotica, 40(9), 593-601. https://doi.org/10.3109/00498254.2010.497565

Bengtsson-Palme J., Kristiansson E., Larsson D.G.J. (2018). Environmental factors influencing the development and spread of antibiotic resistance. FEMS Microbiol. Rev, 42(1), fux053. https://doi.org/10.1093/femsre/fux053

Carvalho I. T., Santos L. (2016). Antibiotics in the aquatic environments: A review of the European scenario. Environment international, 94, 736-757. doi: 10.1016/j.envint.2016.06.025

Chen G. (2020). Xenobiotic metabolism and disposition. Toxicology, 31-42. https://doi.org/10.1016/B978-0-12-813602-7.00003-X

Cvilink V., Lamka J., Skálová L. (2009). Xenobiotic metabolizing enzymes and metabolism of anthelminthics in helminths. Drug Metabolism Reviews, 41(1), 8-26. https://doi.org/10.1080/03602530802602880

Degtyarenko, E.V., Antonovskiy, A.G., Khaliman, I. A., Matsyura, A. V. (2018). Ecological characteristics of mollusks in the Utlyukskij Liman. Ukrainian Journal of Ecology, 8(4), 266-269.

Grenni P., Ancona V., Caracciolo A. (2018). Ecological effects of antibiotics onnatural ecosystems: a review. Microchem. J, 136, 25-39. https://doi.org/10.1016/j.microc.2017.02.006

Kamyshnikov V.S. (2009). Spravochnik po kliniko-biohimicheskim issledovanijam i laboratornoj diagnostike. [Reference book on clinicalbiochemical research and laboratory diagnostics]. MEDpress-inform, Minsk (in Russian).

Khomych,V.V., Mytiai I.S. (2015). Suchasnyi hidroekolohichnyi stan Koropetskoho vodoskhovyshcha richky Koropets [Current hydroecological status of Koropetskiy reservoir (Koropets riverbasin)]. Biological Bulletin of Bogdan Chmelnitskiy Melitopol State Pedagogical University, 5 (3), 140-147 (in Ukrainian). https://doi.org/10.7905/bbmspu.v5i3.992.

Kokunin V.A. (1975). Statisticheskaja obrabotka dannyh pri malom chisle opytov. [Statistical data processing with a small number of experiments]. Ukr. biohim. Zhurn, 6, 776-790 (in Russian).

Kovalakova P., Cizmas L., McDonald T., Marsalek B., Feng M., Sharma V. (2020). Occurrence and toxicity of antibiotics in the aquatic environment: A review. Chemosphere, 251. doi: 10.1016/j.chemosphere.2020.126351

Kurbatova I., Zakharenko M., Tupitska O., Yaremchuk O., Chepil L. (2020). Effect of antibiotics, hormones and anthelmintic on high molecular weight protein fractions in the common carp. Ukrainian Journal of Ecology, 10(2), 76-80. doi: 10.15421/2020_67

Kurbatova I. M., Zaharenko M. O., Chepil' L. V. (2018). Ocinka toksichnoï diï nandrolonu i al'bendazolu na rib za morfologichnimi pokaznikami krovi. [Evaluation of the toxic effects of nandrolone and albendazole on fish by morphological parameters of the blood]. ScienceRise: Biological Science, 1(10), 4-8. (in Ukraine) doi: 10.15587/2519-8025.2018.123900

Lallès J. (2019). Intestinal alkaline phosphatase in the gastrointestinal tract of fish: biology, ontogeny, and environmental and nutritional modulation. Reviews in Aquaculture, 2,555-581. https://doi.org/10.1111/raq.12340

Levchenko V. I., Rozumnik A. V., Novozhic'ka Ju. M. (2012). Laboratorna veterinarna toksikologija. [Laboratory veterinary toxicology]. Bila Cerkva (in Ukrainian).

Li S., Ju H., Zhang J., Chen P., Ji M., Ren J., Zhao Sh. (2019). Occurrence and distribution of selected antibiotics in the surface waters and ecological risk assessment based on the theory of natural disaster. Environmental Science and Pollution Research International, 26(27), 28384-28400. doi: 10.1007/s11356-019-06060-7

Loury O.H., Rosebrough N.J., Farr A.L., Randal R.J. (1951). Protein measurement with the Folin Phenol reagent. Journal of Biological Chemistry, 193(1), 265-275.

Mehed O. B., Jakovenko B. V., Iskevich E. V. (2019). Sezonnaja dinamika toksicheskogo vlijanija gerbicidov na aktivnost' fermentov konechnyh reakcij gljukoneogeneza i soderzhanie gljukozy $v$ tkanjah karpa. [Seasonal dynamics of the toxic effect of herbicides on the activity of enzymes of the final reactions of gluconeogenesis and the glucose content in carp tissues]. Gidrobiologicheskij zhurnal, 1, 73-81 (in Russian)

Policarpo Tonelli F.C., Policarpo Tonelli F.M. (2020). Concerns and Threats of Xenobiotics on Aquatic Ecosystems. Bioremediation and Biotechnology, 3, 15-23. doi:10.1007/978-3-030-46075-4_2

Prichepa M. V., Potrohov O. S., Zin'kovs'kij O. G. (2019). Osoblivosti biohimichnih reakcij rib na antropogennij vpliv za umov urbanizaciï. [Features of biochemical reactions of fish to anthropogenic impact under urbanization]. Gidrobiologicheskij zhurnal, 1, 48-58. (in Ukrainian).

Rodriguez-Mozaz S., Vaz-Moreira I., Giustina S., Llorca M. (2020). Antibiotic residues in final effluents of European wastewater treatment plants and their impact on the aquatic environment. Environment International, 140, 1-11. https://doi.org/10.1016/j.envint.2020.105733

Tertychna O., Bryhas, O., Svaliavchuk L., Miroshnik N. (2017). Ekologichna ocinka stanu atmosfernogo povitrja za umov riznih tehnologij virobnictva produkciï ptahivnictva. [Ecological assessment of atmospheric air under conditions of different technologies of poultry production]. ScienceRise: Biological Science, 3(6), 18-21. (in Ukraine) https://doi.org/10.15587/2519-8025.2017.105062

Woodward K. (2008). Assessment of user safety, exposure and risk to veterinary medicinal products in the European Union. Regulatory Toxicology and Pharmacology, 50(1), 114-128. doi:10.1016/j.yrtph.2007.10.007

\section{Citation:}

Kurbatova, I., Zakharenko, M., Yaremchuk, O., Chepil, L., Polyakovksiy, V. (2020). Effect of chloretracycline and albendazole on alkaline phosphatase activity of carp gill (Cyprinus carpio L.). Ukrainian Journal of Ecology, 194), 257-261.

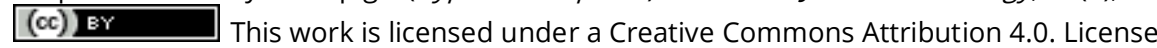

